\title{
INHIBITION OF SPORE GERMINATION AND MYCELIAL GROWTH OF THREE FRUIT ROT PATHOGENS USING SOME CHEMICAL FUNGICIDES AND BOTANICAL EXTRACTS
}

\author{
Most. Ferdousi Begum, Mst. Ferdowsi Mahal* and Md. Shahidul Alam
}

Department of Botany, University of Rajshahi, Rajshahi 6205, Bangladesh

*Corresponding author; email: mini_mahal@yahoo.com

\begin{abstract}
Six chemical fungicides and extracts of 15 locally available plants were tested against three fruit rot pathogens viz. Fusarium oxysporium f. sp. capsici, Rhizopus artocurpi and Alternaria tenuis for the evaluation of inhibition of spore germination and mycelial growth. Among the fungicides tested, all the concentrations of Ridomil showed 100\% inhibition of spore germination and the least inhibition was recorded in case of treatment with Bavistin for F. oxysporium $\mathrm{f}$. sp. capsici. In case of $R$. artocarpi and A. tenuis, Dithene-M 45 showed good inhibitory effects but Thiovit had no inhibitory effect against $A$. tenuis. Both leaf and seed extracts of Azadirachta indica showed good inhibitory effect than tested with other plant extracts. Moringa oleifera extract showed least inhibitory effect against all the fungi tested. Datura metel, Plygonum oriantale, Tagestes patula and Micania scandens also showed promising inhibition on spore germination and mycelial growth of all the pathogens tested.
\end{abstract}

Key words: Fruit rot pathogens, plant extracts, chemical fungicides, spore germination, mycelial growth, PIGR.

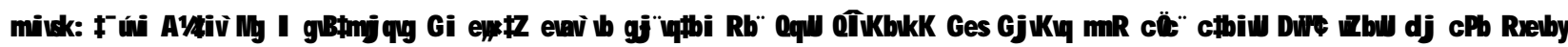

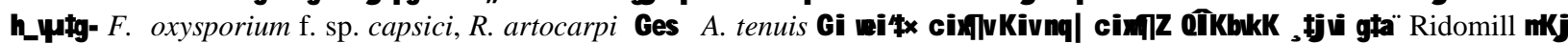

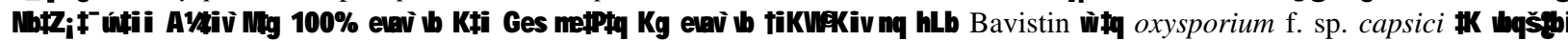

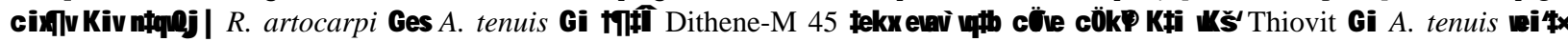

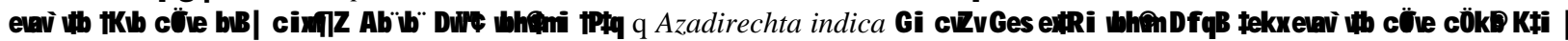
mKj c i $Z$ QÎ vKK

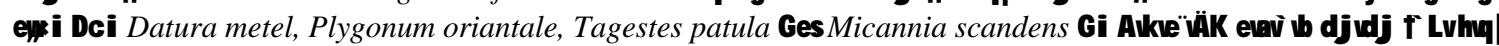

\section{Introduction}

Fruit rot is a very common and destructive disease that causes serious economic loss in production mainly of fruits and vegetables. Alternaria mediated fruit rot is widespread and it causes highly destructive disease of chilli, and yield loss caused by the disease is up to $100 \%$ under congenial environmental conditions (Mahal 2005). Rhizopus rot is also the most common detrimental disease of jackfruit which is caused by Rhizopus artocarpi (Alam et al. 2002a). Use of chemical fungicides is common in fruit rot disease management but they often result problems of toxic residue. Plant extracts are least expensive and cause less health hazards. Several higher plants and their constituents have shown success in plant disease control and are proved to be harmless and non-phytotoxic unlike chemical fungicides (Singh et. al. 1983; Alam et al. 2002b). Evidence suggests that plant extracts can be used against microbes causing diseases in plants. Thus remarkable antifungal effects of plant extracts on the germination of fungal spores (Dubey 1991), and extracts of plant parts for controlling the disease (Pandey et al. 1983; Chary et al. 1984; Singh and Dwivedi 1990) are reported earlier. Here we report the effects of 6 chemical fungicides and extracts of 15 different plants on three fruit rot pathogens, such as $F$. oxysporium $\mathrm{f}$. sp. capsici, $R$. artocarpi and A. tenuis.

\section{Materials and Methods}

Pathogens used: A. tenuis, and F. oxysporium f. sp. capsici were isolated from fruit rot disease affected chillies; and $R$. artocarpi was isolated from infected jackfruit. The fungal pathogens were cultured on PDA (Potato Dextrose Agar) medium and stored at $4^{\circ} \mathrm{C}$ for experimentation.

Effect of chemical fungicides: Spores of three pathogens were taken from 7 day-old cultures on PDA. Spore suspension $\left(10^{3}\right.$ conidia/ml) were made separately against five different concentrations of the chemical fungicides (500, 1000, 1500, 2000 and 2500 ppm) when the threads were thoroughly covered with mycelium and spores. The spores were removed and put in triplicate in fungicidal solution or suspensions in sterile water where different concentrations of each fungicide were used. Five $\mathrm{ml}$ suspensions of each were taken in small sterilized Petri dishes $(65 \mathrm{~mm})$ and kept at $28{ }^{\circ} \mathrm{C}$ for 30 min. Then a drop of lacto phenol cotton blue was added 
to conidial suspension on the slides. The slides were finally examined under microscope $(\times 400)$ for recording the percentage of conidial germination.

Preparation of plant extracts: Extractions of root, seed, bark and leaf tissues were made in $80 \%$ ethyl alcohol following the method described by Mahadevan and Sridhar (1982). Plant tissues (5 g each) were cut into pieces and plunged immediately in boiling alcohol (5-10 ml/g tissues) in a beaker and allowed to boil for 5-10 min. The extracts were made on top of a steam bath and then cooled in a pan of cold water. The tissues were crushed thoroughly in a mortar with a pestle and passed through two layers of cheese-cloth. The ground tissues were re-extracted for 3 min in hot alcohol (2-3 ml/g). The extracts were cooled and passed again through cheese-cloth and filtered through Whatman's No.1 filter paper. Ten $\mathrm{ml}$ of the extracts was evaporated on a steam bath to dryness, $1.25 \mathrm{ml}$ of sterilized distilled water was added per $5 \mathrm{~g}$ tissues and the extracts were used as test materials.

Inhibition of spore germination by plant extracts: Spores from the culture on PDA plates were taken and suspensions of spores were made separately with different plant extracts. These suspensions $(1.25 \mathrm{ml})$ were taken in small sterilized Petri dishes and were kept at $30{ }^{\circ} \mathrm{C}$ for $30 \mathrm{~min}$. A drop of treated spore suspension (with different plant extract) was taken on separate slides in a moisture chamber for 24 hrs of incubation. Then a drop of lacto phenol cotton blue was placed on the spore suspension on each of the slides. The slides were examined under microscope $(\times 40)$ for recording the percentage of spore germination.

Mycelial growth inhibition by plant extracts: For growth inhibition tests stock solutions were prepared by crushing known weight of fresh leaves with distilled water (1:1 by W/V). For barks and fruits, the ratio was 1:2 whereas bulbs were crushed without adding water. The pulverized mass of a plant part was passed through a three-fold fine cloth and was centrifuged at $3000 \mathrm{rpm}$ for $15 \mathrm{~min}$. The supernatant was filtered through Whatman's No. 1 filter paper and the filtrate was collected in $250 \mathrm{ml}$ Erlenmeyer flask. The filtrate of each plant extract was mixed with PDA medium to make 5, 10 and 20\% concentrations. After autoclaving, a plant extract supplemented medium was poured in sterilized Petri plates and allowed to solidify. Each Petri plate received $20 \mathrm{ml}$ of plant extract supplemented medium. This Petri plates were inoculated at the centre with a $5 \mathrm{~mm}$ agar disc, cut from the margin of actively growing culture of the pathogens. In the control, a Petri plate containing PDA medium with requisite amount of sterilized water instead of a plant extract was also inoculated with a plant pathogen. Three replicates were maintained in each case and inoculated Petri plates were kept at $28^{\circ} \mathrm{C}$. The radial growth of the colonies was measured after 7 days of incubation. The two readings in the control and treatment lines were transformed into percent inhibition of radial growth (PIRG) using the following formula (Skidmore and Dickenson 1976): \% Growth inhibition $=(\mathrm{C}-\mathrm{T}) / \mathrm{C} \times 100$, where $\mathrm{C}=$ growth in the control and $\mathrm{T}=$ growth in the treatment.

Statistical analyses: For analyzing the experimental data, arcsine angular transformations were made. Least significant differences (LSD) were determined wherever the calculated $\mathrm{F}$ values (analysis of variance, ANOVA) were significant at 5\% level (Snedecor and Cochran 1980).

\section{Result and Discussion}

Effects of chemical fungicides on the inhibition of spore germination: Data presented in Table 1 reveal that Ridomil was the most effective fungicide against $F$. oxysporium while Bavistin had the least effect, DitheneM 45 showed the highest and Thiovit the lowest against $R$. artocarpi, and Dithene-M 45 had the highest and Bavistin the lowest effects against $A$. tenuis but Thiovit showed no inhibitory effect on this species. All 6 chemical fungicides exhibited significant inhibition of spore germination against $F$. oxysporium $\left(\mathrm{F}_{5,20}=12.52\right.$; $\mathrm{P}<0.01)$, R. artocarpi $\left(\mathrm{F}_{5,20}=9.61 ; \mathrm{P}<0.01\right)$ and $A$. tenuis $\left(\mathrm{F}_{5,20}=10.77 ; \mathrm{P}<0.01\right)$.

Sekhar et al. (1989) reported field trials on $Z$. mauritiana cv. kajhali infected by Prarthgada zizyphi with fungicides applied as spray and observed that Bavistin at $0.1 \%$ gave the lowest disease incidence followed by $0.2 \%$ Dithene-M 45. An economically viable measure was suggested by Singh et al. (1990) to farmers where Alternaria brassicae induced leaf spot under field conditions was controlled by seven fungicides including Bavistin and Dithene-M 45. Ridomil, Dithehe-M 45, Cupravit, Bavistin and Rovral were found effective fungicides against $A$. tenuis in field experiments ((Alam et al. 1999). The present results lend support to the above three findings.

Effects of plant extracts on the inhibition of spore germination: Leaf extracts of $A$. indica showed highest inhibitory effect and $M$. oleifera leaf the lowest against $F$. oxysporum f. sp. capsici, leaf and seed extracts of $A$. indica inhibited the highest spore germination whereas Terminalia arjuna fruit had no effect on $R$. artocarpi, and $A$. indica leaf inhibited the most but $M$. oleifera leaf had none inhibitory effects on A. tenuis (Table 2). A significant inhibitory effect of all plant extracts on spore germination in the fruit rot pathogens was evident $\left(F_{16,32}=3.92 ; \mathrm{P}<0.01\right)$. 
A. indica inhibiting growth of A. alternate, Bipolaries sorokiniana and several other fungi have been reported (Singh and Dwivedi, 1990; Alam et al. 2002a). As regards the leaf extract, the most promising fungitoxic effect was recorded in case of $M$. scendens $(63.10 \%$ and $61.80 \%), P$. orientale $(60 \%$ and $58.30 \%)$, D. metel (55.21\% and 57\%) and T. patula (58.30\% and 56.20\%) against $F$. oxysporum f. sp. capsici and A. tenuis. $R$. artocarpi plant extracts were less effective and there was no effect of fruit extract of $T$. arjuna against $R$. artocarpi and leaf extract of $M$. oleifera against $A$. tenuis. Alam et al. (1999) reported the antifungal effects of $V$. rosea and $A$. indica against $A$. tenuis of chilli fruit rot pathogen. Akhter et al. (2006) reported that Vinca rosea, Piper betle and A. indica extracts have inhibitory (100\%) effect against spore germination of Bipolaris sorokiniana. The fungitoxicity of the leaf extract of Datura sp. has been reported earlier by several investigators against $F$. oxysporum f. sp. ciceri (Podwick) Snyd and Hans (Bashar and Rai, 1991) and R. solani (Hossain et al., 1993). Hossain et al. (1993) and Anwar et al. (1994) reported antifungal activity of the leaf extracts of $M$. scendens and $P$. orientale on a number of pathogens including Alternaria sp. and Rhizopus sp. The present study indicated that the inhibitory effect of the plant parts on spore germination of $F$. oxysporum, $R$. artocarpi, A. tenuis might be attributed to the presence of some partially effective antifungal ingredients.

Effects of plant extracts on the inhibition of mycelia growth: A. indica leaf extracts at $20 \%$ concentration inhibited the highest mycelial growth in all the fruit rot pathogens, whereas the lowest inhibitory effects were shown by $M$. oleifera leaf extracts in F. oxysporum f. sp. capsici and $R$. artocarpi, and T. arjuna bark extracts in A. tenuis (Table 3). ANOVA on the mycelial growth inhibition data showed highly significant effects of the plant extracts on $F$. oxysporum $\left(\mathrm{F}_{16,32}=31.57 ; \mathrm{P}<0.001\right)$, R. artocarpi $\left(\mathrm{F}_{16,32}=57.23 ; \mathrm{P}<0.001\right)$ and $A$. tenuis $\left(\mathrm{F}_{16,32}=35.14 ; \mathrm{P}<0.001\right)$.

In previous work Ogbebor et al. (2007) reported that extracts of Ocimum basilicum L. and Allium sativum L. exhibited total inhibitory effects on the mycelial growth of Colletotrichum gloeosporioides. It was also observed that although not promising but still the fungitoxic effect of these plant extracts persisted even at 5\% concentration. This observation suggests that fungitoxicity of the plant extracts have been found to be promising against plant pathogens like Fusarium sp. and Alternaria sp. and can be increased further by using these plant extracts at higher concentrations.

\section{Conclusion}

Chemical fungicides and extracts of locally available plants tested against three fruit rot pathogens inhibited spore germination and mycelial growth significantly. Effects of two fungicides (Ridomil and Dithene-M45) and a plant extract (Azadirachta indica) were promising compared to others.

\section{References}

Akhter N, Begum MF, Alam S, and Alam MS. 2006. Inhibitory effect of different plant extracts, cowdung and cow urine on conidial germination of Bipolaris sorokiniana. J. bio-sci. 14: 87-92

Alam S, Akther N, Begum F, Banu MS, Islam MR, Chowdhury AN and Alam MS. 2002b. Antifungal activities (in vitro) of some plant extracts and smoke on four fungal pathogens of different hosts. Pakistan J. Bio. sci. 5(3): 307-309.

Alam S, Alam MS and Mahal F. 1999. Growth inhibition (in vitro) of chilli fruit rot pathogen Alternaria tenuis. $J$. Asiat. Soc. Bangladesh, Sci. 2??: 211-226.

Alam S, Begum MF, Alam MS and Chowdhury AN. 2002a. In vitro germination of Rhizopus artocarpi spores in different substrates- a jackfruit rot pathogen. Rajshahi Univ. Studies (Part B) 30: 179-183.

Anwar MN, Sing P, Begum J and Chowdhury JU. 1994. Antifungal activity of some selected plant extracts on phytopathogenic fungi. Bangladesh J. Bot. (2??): 23-26.

Basher MA and Rai B. 1991. Antifungal activity of extracts of some plant parts against Fusarium oxysporium f. sp. ciceri. Bangladesh J. Bot. 20(2): 219-222.

Chary MP, Reddy EA and Reddy SM. 1984. Screening of indigenous plants for their antifungal principles. Pesticides 18: 17-18.

Dubey RC. 1991. Fungicidal effect of essential oils of three higher plants on sclerotia of Macrophomina phaseolina. Indian Phytopath. 44: 241-243.

Hossain MM, Chowdhury N and Khan AL. 1993. Effect of funsicides on the production of healthy onion seeds. Abstract 5th Biennial Conf. Bamgladesh Phytopathol. Soc. p. 7.

Mahal MF. 2005. Study of fruit rot disease of chilli caused by Alternaria tenuis and its control

Bangladesh. Unpubl. Ph. D. Thesis. Department of Botany, University of Rajshahi. Bangladesh....pp.

Mohadevan A and Sridhar H. 1982. Methods in Physiological Plant Pathology ( $2^{\text {nd }}$ edn). Sivakami Publications, Madras, India. 316 pp. 
Table 1. Effects of six fungicides on the inhibition of spore germination of three fruit rot pathogens 30 min after immersion.

\begin{tabular}{|c|c|c|c|c|c|c|c|}
\hline \multirow{2}{*}{ Pathogens } & \multirow{2}{*}{ Fungicides } & \multicolumn{5}{|c|}{$\%$ inhibition of spore germination at concentrations (ppm) ${ }^{\mathrm{a}}$} & \multirow{2}{*}{$\begin{array}{c}\text { Correlation (r) } \\
\text { values }\end{array}$} \\
\hline & & 500 & 1000 & 1500 & 2000 & 2500 & \\
\hline \multirow{6}{*}{$\begin{array}{l}\text { F. oxysporum } \\
\text { f. sp. capsici }\end{array}$} & Cupravit & 23(77) & $24(76)$ & $31(69)$ & $33(67)$ & $39(61)$ & 0.977 \\
\hline & Ridomil & $100(00)$ & $100(00)$ & 100(00) & $100(00)$ & 100(00) & - \\
\hline & Rovral & $10(90)$ & $23(77)$ & $27(73)$ & $33(67)$ & $35(65)$ & 0.954 \\
\hline & Thiovit & $25(75)$ & $27(73)$ & $29(71)$ & $32(68)$ & 33(67) & 0.992 \\
\hline & Dithene-M 45 & 11(89) & 17(83) & 21(79) & $33(67)$ & $35(65)$ & 0.979 \\
\hline & Bavistin & $7(93)$ & $15(85)$ & 19(81) & $22(78)$ & $25(75)$ & 0.973 \\
\hline F value (LSD $\left.{ }_{0.05}\right)$ & \multicolumn{7}{|c|}{$12.52 * *(12.398)$} \\
\hline \multirow{6}{*}{ R. artocarpi } & Cupravit & $18(82)$ & $29(71)$ & $33(67)$ & $45(55)$ & $70(30)$ & 0.956 \\
\hline & Ridomil & 33(67) & $37(63)$ & $40(60)$ & $41(59)$ & $45(55)$ & 0.985 \\
\hline & Rovral & $18(82)$ & $21(79)$ & $28(72)$ & $57(43)$ & $75(25)$ & 0.948 \\
\hline & \begin{tabular}{|l} 
Thiovit \\
\end{tabular} & $25(75)$ & $29(71)$ & $32(68)$ & $38(62)$ & $40(60)$ & 0.991 \\
\hline & Dithene-M 45 & 33(67) & (69)37 & $75(25)$ & $77(33)$ & 81(19) & 0.914 \\
\hline & Bavistin & $31(69)$ & $37(63)$ & $40(60)$ & $43(57)$ & $47(53)$ & 0.990 \\
\hline F value $\left(\mathrm{LSD}_{0.05}\right)$ & \multicolumn{7}{|c|}{$9.61 *(31.517)$} \\
\hline \multirow{6}{*}{ A. tenuis } & Cupravit & $87(13)$ & $89(11)$ & 95(05) & $98(02)$ & $100(00)$ & 0.983 \\
\hline & Ridomil & $81(19)$ & $83(17)$ & 91(09) & $95(05)$ & $100(00)$ & 0.988 \\
\hline & Rovral & 83(17) & $88(12)$ & 93()07 & $97(03)$ & $100(00)$ & 0.995 \\
\hline & Thiovit & $00(100)$ & $00(100)$ & $00(100)$ & $00(100)$ & $00(100)$ & - \\
\hline & Dithene-M 45 & $96(04)$ & $99(01)$ & $100(00)$ & $100(00)$ & $100(00)$ & 0.821 \\
\hline & Bavistin & $37(63)$ & $39(61)$ & 41(59) & $43(57)$ & $48(52)$ & 0.974 \\
\hline F value $\left(\mathrm{LSD}_{0.05}\right)$ & & & & $(9.489)$ & & & \\
\hline
\end{tabular}

$\mathrm{a}=$ mean of three replicates; values in parentheses indicate $\%$ spore germination; $* *=\mathrm{P}<0.01$.

Table 3. Effects of plant extracts on the inhibition of mycelial growth of three fruit rot pathogens in three different concentrations after 7 days' incubation.

\begin{tabular}{|c|c|c|c|c|c|c|c|c|c|c|}
\hline \multirow{3}{*}{ Plant species } & \multirow{3}{*}{ Plant parts } & \multicolumn{9}{|c|}{ \% inhibition of mycelia growth in different concentrations (\%) ${ }^{\mathrm{a}}$} \\
\hline & & \multicolumn{3}{|c|}{ F. o. f. sp. capsici } & \multicolumn{3}{|c|}{ R. artocarpi } & \multicolumn{3}{|c|}{ A. tenuis } \\
\hline & & 5 & 10 & 20 & 5 & 10 & 20 & 5 & 10 & 20 \\
\hline Azadirachta indica & Leaf & 51.10 & 56.20 & 65.30 & 72.00 & 87.00 & 89.00 & 55.10 & 57.00 & 77.00 \\
\hline Azadirachta indica & Seed & 50.20 & 53.10 & 61.80 & 76.00 & 83.00 & 88.00 & 51.00 & 52.00 & 69.00 \\
\hline Blumea lacera & Leaf & 11.30 & 19.10 & 27.33 & 09.50 & 11.20 & 17.30 & 05.20 & 13.30 & 16.50 \\
\hline Datura metel & Leaf & 42.30 & 52.10 & 57.20 & 11.10 & 17.20 & 27.80 & 28.58 & 42.60 & 55.90 \\
\hline Euphorbia plucherrima & Leaf & 09.50 & 11.30 & 19.80 & 03.50 & 05.20 & 06.23 & 11.10 & 19.20 & 20.10 \\
\hline Mentha spicata & Leaf & 07.50 & 11.50 & 16.07 & 02.20 & 04.20 & 05.90 & 08.30 & 11.20 & 15.31 \\
\hline Mikania scandens & Leaf & 11.15 & 31.43 & 61.00 & 09.70 & 11.30 & 19.45 & 22.70 & 37.10 & 63.10 \\
\hline Moringa oleifera & Leaf & 05.90 & 07.50 & 12.50 & 00.00 & 00.00 & 00.00 & 05.30 & 09.10 & 11.20 \\
\hline Polygonum orientale & Leaf & 35.50 & 47.20 & 50.30 & 10.20 & 13.10 & 19.50 & 23.00 & 30.00 & 53.00 \\
\hline Psidium guajava & Leaf & 12.00 & 19.50 & 24.15 & 03.50 & 05.20 & 09.78 & 11.20 & 13.30 & 18.50 \\
\hline Tagestes patula & Leaf & 25.10 & 33.30 & 47.50 & 01.20 & 02.50 & 05.10 & 45.10 & 52.20 & 58.30 \\
\hline Zingiber officinale & Rhizome & 13.00 & 17.50 & 22.13 & 01.00 & 01.90 & 02.20 & 07.50 & 11.30 & 19.20 \\
\hline Curcuma longa & Rhizome & 21.50 & 32.50 & 39.90 & 32.00 & 04.10 & 04.50 & 31.50 & 32.50 & 40.25 \\
\hline Terminalia arjuna & Bark & 21.00 & 27.50 & 35.50 & 08.10 & 09.50 & 13.50 & 01.10 & 02.30 & 03.31 \\
\hline Terminalia arjuna & Fruit & 07.50 & 11.50 & 22.83 & 00.00 & 00.00 & 00.00 & 11.50 & 19.50 & 25.50 \\
\hline Allium сера & Bulb & 37.10 & 39.20 & 43.20 & 01.20 & 02.30 & 03.10 & 21.50 & 27.80 & 37.50 \\
\hline Allium sativum & Bulb & 09.20 & 11.20 & 24.51 & 05.90 & 06.10 & 07.06 & 20.10 & 25.20 & 28.21 \\
\hline F value $\left(\mathrm{LSD}_{0.05}\right)$ & Plant extracts & \multicolumn{3}{|c|}{$31.57 * *(5.337)$} & \multicolumn{3}{|c|}{$57.23 * *(7.127)$} & \multicolumn{3}{|c|}{$38.14 * *(5.635)$} \\
\hline
\end{tabular}

$\mathrm{a}=$ Mean of three replications; ${ }^{* *}=\mathrm{P}<0.01$ 
Table 2. Effects of plant extracts on the inhibition of spore germination of three fruit rot pathogens 30 min after immersion.

\begin{tabular}{|c|c|c|c|c|}
\hline \multirow[b]{2}{*}{ Plant species } & \multirow[b]{2}{*}{ Plant parts } & \multicolumn{3}{|c|}{ \% inhibition of spore germination ${ }^{\mathrm{a}}$} \\
\hline & & $\begin{array}{c}\text { F. oxysporum f. sp. } \\
\text { capsici }\end{array}$ & R. artocarpi & A. tenuis \\
\hline Azadirachta indica & Leaf & $87.00(13.00)$ & $100.00(00)$ & $82.00(18.00)$ \\
\hline Azadirachta indica & Seed & $75.00(25.00)$ & $100.00(00)$ & $66.00(44.00)$ \\
\hline Blumea lacera & Leaf & 17.33(82.67) & $3.55(96.45)$ & $16.15(83.85)$ \\
\hline Datura metel & Leaf & $55.21(44.79)$ & $27.00(73.00)$ & $57.00(43.00)$ \\
\hline Euphorbia plucherrima & Leaf & $22.50(77.50)$ & $9.80(90.20)$ & $10.50(89.50)$ \\
\hline Mentha spicata & Leaf & 25.31(74.69) & 21.07(78.93) & $5.90(94.10)$ \\
\hline Mikania scandens & Leaf & $63.10(36.90)$ & $13.00(87.00)$ & $61.80(38.20)$ \\
\hline Moringa oleifera & Leaf & $2.35(97.65)$ & $2.85(97.15)$ & $0.00(100)$ \\
\hline Polygonum orientale & Leaf & $60.00(40.00)$ & $21.45(78.55)$ & $58.30(41.70)$ \\
\hline Psidium guajava & Leaf & 18.82(81.18) & $24.10(75.90)$ & $8.20(91.80)$ \\
\hline Tagestes patula & Leaf & $58.30(41.70)$ & $15.00(85.00)$ & $56.20(43.80)$ \\
\hline Zingiber officinale & Rhizome & $21.00(79.00)$ & $3.10(96.90)$ & $37.00(63.00)$ \\
\hline Curcuma longa & Rhizome & $31.00(69.00)$ & $7.00(93.00)$ & $41.00(59.00)$ \\
\hline Terminalia arjuna & Bark & $32.50(67.50)$ & $19.00(81.00)$ & $31.00(69.00)$ \\
\hline Terminalia arjuna & Fruit & $22.00(78.00)$ & $0.00(100)$ & $27.00(73.00)$ \\
\hline Allium сера & Bulb & $41.20(58.80)$ & $12.00(88.00)$ & $32.20(77.80)$ \\
\hline Allium sativum & Bulb & $34.10(65.90)$ & $17.00(83.00)$ & $38.20(61.80)$ \\
\hline F value $\left(\mathrm{LSD}_{0.05}\right)$ & & 3.92 & & \\
\hline
\end{tabular}

$\mathrm{a}=$ mean of three replications; values in parentheses indicate \% spore germination; $*=\mathrm{P}<0.01$.

Ogbebor NO, Adekunle AT and Enobakhare DA. 2007 Inhibition of Colletotrichum gloeosporioides (Penz) Sac. causal organism of rubber (Hevea brasiliensis Muell. Arg.) leaf spot using plant extracts. African $J$. Biotechnol. 6(3): 213-218,

Pandy RS, Bhargava SN, Shukla DN and Dwivedi DK. 1983. Control of pestalotia fruit rot of guava by leaf extracts of two medicinal plants. Rev. Maxicana de Fitopatologia 2: 15-16.

Sekhar MJ, Vinayagamurthy A, Subramanian S and Anbusm S. 1989. Control of black spot of ber (Ziziphus mauritiana). South Indian Horticul. 37: 344-345.

Singh BP, Singh SP and Mohammad A. 1990. Economic efficacy of different fungicides for the control of leaf spot of cauliflower. Indian Phytopathol. 43: 207-209.
Singh RK and Dwivedi RS. 1990. Fungicidal properties of neem and babul gum against Sclerotium rolfsii. Acta. Bot. Indica 18: 260-262.

Singh Y, Tripathi RD, Tripathi NN and Dixit SN. 1983. The isolation and properties of fungitoxic principle from Zingiber officinale. Indian J. Plant. Pathol. 1: 89-96.

Skidmore AM and Dickenson CH. 1976. Colony interaction and hyphal interference between Septoria nodorum and phylloplane fungi. Trans Brit. Mycol. Soc. 66(11): 57-64.

Snedecor GW and Cochran WG. 1980. Statistical Methods $\left(7^{\text {th }}\right.$ edn). Iowa State University Press, Iowa USA. 507 pp.

Manuscript received on 24 May 2010 and revised on 10 November 2010. 